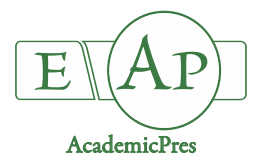

\title{
Influence of Volatile Peppermint (Mentha $\times$ piperita L.) Compounds on Germination and Seedling of Radish (Raphanus sativus L. var. radicula Pers.) Growth
}

\author{
Renata SZAFRANIEC ${ }^{1}$, Katarzyna MOŻDŻEŃ ${ }^{2 *}$, \\ Beata BARABASZ-KRASNY ${ }^{2}$, Peiman ZANDI $^{3}$, Yaosheng WANG ${ }^{3}$ \\ ${ }^{1}$ Kraków Institute for Development and Education, Wielicka 42/105 St., 30-552 Kraków, Poland; renata.purzycka@op.pl \\ ${ }^{2}$ Pedagogical University of Cracow, Institute of Biology, Podchorażych 2 St., 30-084 Kraków, \\ Poland; kasiamozdzen@interia.pl ("*orrespondingauthor); beata.barabasz-krasny@up.krakow.pl \\ ${ }^{3}$ Institute of Environment and Sustainable Development in Agriculture, Chinese Academy of Agricultural Science, Beijing 100081, \\ P.R.China; z_rice_b@yahoo.com;wangyaosheng@caas.cn
}

\begin{abstract}
The research concerns the influence of volatile compounds contained in dry peppermint leaves (Mentha xpiperita L.) on germination and seedling characteristics of radish (Raphanus sativus $\mathrm{L}$. var. radicula Pers. 'Półdługa'). 1, 5 and $10 \mathrm{~g}$ of dried peppermint leaves were added respectively into containers, and then Petri dishes with radish seeds were placed in each of them. The control was performed without dried mint. Radish seeds treated with volatile mint compounds in the lowest $1 \mathrm{~g}$ dose germinated similarly to the control sample. The other two doses, 5 and $10 \mathrm{~g}$, inhibited the process of seeds germination. Allelophatins from $M$. xpiperita at $1 \mathrm{~g}$ of dose had also a stimulating effect on the growth of radish seedlings, especially its roots. The growth of underground organs was also observed at 5 and $10 \mathrm{~g}$ doses. For radishes grown in the lowest dose of allelopathic compounds, the values of fresh and dry masses and percentage water content were highest. As the dose of emitters increased, a slight decrease in the value of these parameters was observed, as compared to the control.
\end{abstract}

Keywords: emitters; germination index; growth; mass

\section{Introduction}

Allelopathy among plants is a natural ecological phenomenon known and used in agriculture since the earliest times (Finch et al., 2003; Inderjit and Duke, 2003; Willis, 2007; Zeng, 2014). The author of the first contemporary definition of this phenomenon was the Austrian physiologist Hans Molisch (1937), according to which 'allelopathy' is both a negative and a positive biochemical effect of one plant on another or on microorganisms. The term was clarified by Elroy Rice (1984) and referred to any direct or indirect harmful or beneficial effect of one plant (including microorganisms) on others, by producing chemicals that are released into the environment. In 1996, the International Association of Allelopathy extended the definition of allelopathy by describing it as: any process involving secondary metabolites produced by plants, microorganisms, viruses and fungi that affect the growth and development of agricultural and biological systems. Allelopathic substances in liquid or volatile form can stimulate or inhibit plant germination and growth, as well as enable the development of crops with a low content of phytotoxic compounds (Macias et al., 2003; Zeng et al., 2008).

The group of plants showing pronounced allelopathic properties includes, among others peppermint Mentha xpiperita L. (syn. M. xpiperata (L.) Hudson, M. xcitrata Ehrh.), from the family Lamiaceae Lindl. It is a hybrid of two species: M. aquatica L. and M. spicata L. (Najda, 2017). Peppermint is a perennial herbaceous plant, reaching 50-90 $\mathrm{cm}$ in height. It has erected, branching stems, from which usually lanceolate leaves grow, with a pointed tip, serrated edge and asymmetrical base. They reach up to $9 \mathrm{~cm}$ long and $3 \mathrm{~cm}$ wide. This plant forms small flowers (5-6 mm long), creating a semi-ear, with cylindrical shape. The fruits are schizocarps (lat. schizocarpium), disintegrating into 4 parts. Usually, it propagates vegetatively through rhizomes. Ancient Egyptians dealt with its cultivation, and now it is cultivated, among others in: England, Bulgaria, France, Germany, Poland, Russia, Hungary and the United States 
1278

(Kohlmünzer, 2003; Singh et al., 2015). This plant owes its popularity to the high content of medicinal essential oils in the leaves, which include primarily: menthol and its isomers, menthol esters, ketones and terpene oxides (Eteghad $e t$ al., 2009; Derwich et al., 2010; Kizil et al., 2010; Najda, 2015; 2017).

Radish (Raphanus sativus L. var. radicula Pers.) is a botanical variety of ordinary radish ( $R$. sativus $\mathrm{L}$.), widely cultivated in Poland and around the world. Is an annual or biennial plant, in crop it is growing up to $60 \mathrm{~cm}$ in height. It forms white flowers gathered in racemes, which later transform into siliques - a fruit typical of the entire Brassicaceae Burnett family. All radish cultivars are a rich source of folic acid, vitamins B1, B2, B6 and C, magnesium, copper, calcium and iron, as well as indoles, flavonoids (zeaxanthin, lutein and beta-carotene) and antioxidants (suforafen, isothiocyanate) (Beevi et al., 2010; 2012). In soil cultivations, radish does not require a long vegetation period, from 30 to 50 days from sowing to full maturity (Krawiec et al., 2012). In addition, it is characterised by rapid seed germination, which contributed to its choice as an acceptor plant - subjected to volatile allelopathic compounds from dry peppermint leaves.

The aim of the study was to determine the effect of volatile compounds contained in dry peppermint leaves $(M$. xpiperita), used in different doses $(1,5,10 \mathrm{~g})$, on selected phenotypic features of radish $(R$. sativus var. radicula 'Półdługa'), in the early stages of its growth and development. The following indicators were adopted as measures of allelopathic effects: radish seed germination index [1], length of underground, aboveground and whole seedlings [2], as well as fresh and dry mass and percentage water content in 7-day radish seedlings [3].

\section{Materials and Methods}

\section{Plant material}

In the experiment radish seeds in the 'Półdługa' cultivar (Raphanus sativus var. radicula 'Półdługa'), purchased at the garden store of POLAN sp.z.o.o. (Cracow, Poland) were used. Dried peppermint leaves (Menthae piperitae folium) from Flos company (Morsko, Poland) were obtained.

\section{Biologicalmaterial \\ Preparation of seeds and emitters}

Rinsed under running water, morphologically similar radish seeds, were put with tweezers on Petri dishes $(\varnothing 9 \mathrm{~cm})$ with a triple layer of Whatman filter paper (No. 30) moistened with $6 \mathrm{ml}$ distilled water. 1,5 and $10 \mathrm{~g}$ of dried peppermint leaves were placed successively into plastic, opaque 1 liter containers in the dark (experimental containers with perforate $-1 \mathrm{~mm}$ holes, for access of air), and then two Petri dishes with radish seeds were put in each. The control group was radish seeds in Petri dishes placed in a container without dried peppermint leaves. During the experiment, the seeds were watered with distilled water.

Seed germination took place for 7 days without access to light, at room temperature $24{ }^{\circ} \mathrm{C} \pm 1{ }^{\circ} \mathrm{C}$ and relative humidity ( $\mathrm{RH}$ 60-70\%). After each day, the number of germinated radish seeds was checked. Germinated seeds were considered those, whose sprouts reached a length of at least half the size $(2 \mathrm{~mm})$ of radish seeds.

\section{Germination indexes}

Germination capacity characterisation of radish seeds, under the influence of volatile compounds of dried peppermint, was based on various germination coefficients, whose formulas are summarised in Table 1 (Islam and KatoNoguchi, 2014). Germination percentage (GP), germination index (GI), speed of emergence (SE), coefficient of the rate of germination (CRG), seedling vigour index (SVI) and time required for $50 \%$ germination $\left(\mathrm{T}_{50}\right)$ were measured.

\section{Biometric analysis}

The length of radish seedlings grown in the presence of volatile compounds released from dry peppermint leaves was determined using an analog caliper (Alfa L-150, Poland), with an accuracy of $1 \mathrm{~mm}$. The length of whole seedlings, roots and hypocotyls were carried out according to the formula (Islam and Kato-Noguchi, 2012):

$$
\mathrm{IP}=\left(1-\left(\mathrm{L}_{\mathrm{E}} / \mathrm{L}_{\mathrm{C}}\right)\right) \times 100
$$

Table 1. Germination index formulas

\begin{tabular}{|c|c|c|}
\hline Germination index & Formula & Author \\
\hline $\begin{array}{c}\text { GP } \\
\text { (Germination percentage) }\end{array}$ & $\begin{array}{c}\mathrm{GP}=[\text { Number of germinated seeds at everyday } / \text { Total number of seeds sets for } \\
\text { bioassay }] \times 100\end{array}$ & Global method \\
\hline $\begin{array}{c}\text { GI } \\
\text { (Germination index })\end{array}$ & $\begin{array}{c}\text { [Number of germinated seeds/Days of first count }]+\ldots+[\text { Number of germinated } \\
\text { seeds/Days of last or final count }]\end{array}$ & $\operatorname{AOSA}(1983)$ \\
\hline $\begin{array}{c}\text { SE } \\
\text { (Speed of emergence) }\end{array}$ & $\begin{array}{c}\mathrm{SE}=(\text { Number of germinated seeds at the starting day of germination/Number of } \\
\text { germinated seeds at the final days of measurement }) \times 100\end{array}$ & Islam et al. (2009) \\
\hline $\begin{array}{l}\text { CRG } \\
\text { (Coefficient of the rate of } \\
\text { germination) }\end{array}$ & $\begin{aligned} \mathrm{CRG}=[(\mathrm{n} 1+\mathrm{n} 2+\mathrm{nn}) /((\mathrm{n} 1 \times \mathrm{T} 1)+(\mathrm{n} 2 \times \mathrm{T} 2)+(\mathrm{n} 3 \times \mathrm{T} 3)+\ldots)] \times 100 \\
\mathrm{n} 1=\text { number of germinated seed } \text { on time } \mathrm{T} 1 \\
\mathrm{n} 2=\text { number of germinated seeds on time T2 } \\
\mathrm{n} 3=\text { number of germinated seeds on timeT3 }\end{aligned}$ & $\begin{array}{l}\text { Bewley and Black (1985), Chiapusio et. } \\
\qquad \text { al. (1997) }\end{array}$ \\
\hline $\begin{array}{l}\text { SVI } \\
\text { (Seedling vigour index) }\end{array}$ & SVI $=($ Seedling length $(\mathrm{mm}) \times$ Germination percent $) / 100$ & Islam et al. (2009) \\
\hline $\begin{array}{l}\quad \mathrm{T}_{50} \\
\text { (Time required for } \\
\text { 50\%germination) }\end{array}$ & $\begin{array}{l}\left.\qquad T_{50}=t i+[(N / 2)-n j) \times(t i-t j)\right] /(n i-n j) \\
N \text { is the final number of germination and ni, nj cumulative numbers of seeds } \\
\text { germinated bjy adjacent counts at times ti and tj when } n i<N / 2<n j\end{array}$ & $\begin{array}{l}\text { Coolbear et al. (1984), Farooq et al. } \\
\qquad \text { (2006) }\end{array}$ \\
\hline
\end{tabular}


where:

IP - growth inhibition index [\%]

$\mathrm{L}_{\mathrm{E}}$ - seedlings length $(\mathrm{mm})$ treated with emitter data

$\mathrm{L}_{\mathrm{C}}$ - seedlings length $(\mathrm{mm})$ from the control

\section{Fresh, dry mass and water content}

The fresh mass of 7-day radish seedlings on a laboratory scale (WPS 120 Radwag, Poland) was determined. To obtain a dry mass, the plant material was dried for 48 hours at $105^{\circ} \mathrm{C}$ in a dryer (WAMED SUP 100, Polska), and then were weighted. On the basis of the mass values obtained, the percentage water content was determined according to the formula: $100-[($ dry mass $\times 100) /$ fresh mass $]$.

\section{Statistical analysis}

The experiment was carried out in 2 independent repetitions on 25 seeds in each of the tested samples. To verify the differences between the means $( \pm S D)$ obtained, the one-way ANOVA / MANOVA parametric test was used, based on Duncan's post hoc test, for homogeneous groups with level of 0.05 ( $\mathrm{p} \leq 0.05)$. All calculations were made using the StatSoft, Inc. (2018). STATISTICA (data analysis software system), version 13.1. www.statsoft.com.

\section{Results}

Germination capacity of Raphanus sativus var. radicula 'Półdługa' seeds from the control group after 7 days was $90 \%$ (Fig. 1). The same result was obtained for seeds germinated under the influence of emitters from dry leaves Mentha xpiperita at a dose of $1 \mathrm{~g}$. Higher doses of dried peppermint ( 5 and $10 \mathrm{~g}$ ) caused in slightly lower radish seeds germination capacity. In the case of seeds germinated at the highest dose of $10 \mathrm{~g}$ volatile peppermint, germination began only on the 2 day of observation, while in the remaining groups, germination took place as early as 24 hours from the start of the experiment. In the remaining two groups, 5 and $10 \mathrm{~g}$ emitters, the highest number of germinated radish seeds was observed on the $4^{\text {th }}$ day.

The germination index (GI) reached the highest values after 7 days of the experiment for radish seeds from control group and peppermint emitters of $1 \mathrm{~g}$ (Fig. 2). GI of radish seeds was significantly reduced for the sample with seeds germinating in the highest dose of emitters, which can be clearly seen on each day of germination. On the third day of the experiment, the GI of the radish exposed to a $1 \mathrm{~g}$ dose of volatile compounds was higher than the GI of the radish from the control. On the fourth and each subsequent day of experiment, none of the tested radish samples with $M$. $\times$ piperita emitters reached a GI value higher than the seeds germinating in the control sample.

The seed emergence (SE) index achieved the highest in the radish seeds from the control sample and the sample treated with $1 \mathrm{~g}$ of mint emitters (Fig. 3). The values lower by nearly two percentage points concerned radish seeds germinating in conditions of $10 \mathrm{~g}$ dried dose. Seeds treated with 5 g emitter dose had the lowest SE.

In the case of coefficient of the rate of germination (CRG), it was noted that as the dose of allelopathic compounds increased, its value decreased, and it was highest in the control (Fig. 3). The differences between the value of this index for radish seeds from the control and samples treated with 1 and $5 \mathrm{~g}$ doses of emitters from dry $M$. xpiperita leaves were small. The most significant change in the value of this parameter was visible for radish seeds germinating in conditions of $10 \mathrm{~g}$ dried dose.

Seed vigour index (SVI) reached the highest values for radish seeds germinating in the presence of $1 \mathrm{~g}$ dose of dried peppermint, compared to the values from the control and the other two samples (Fig. 4). These values were the highest, both for the whole seedling and for the root and hypocotyl separately. SVI for whole radish seedlings from the control sample was lower than in the case described above. A relationship was observed here that the higher the dose of allelopatins, the lower the SVI values for whole seedlings, their roots and hypocotyls.

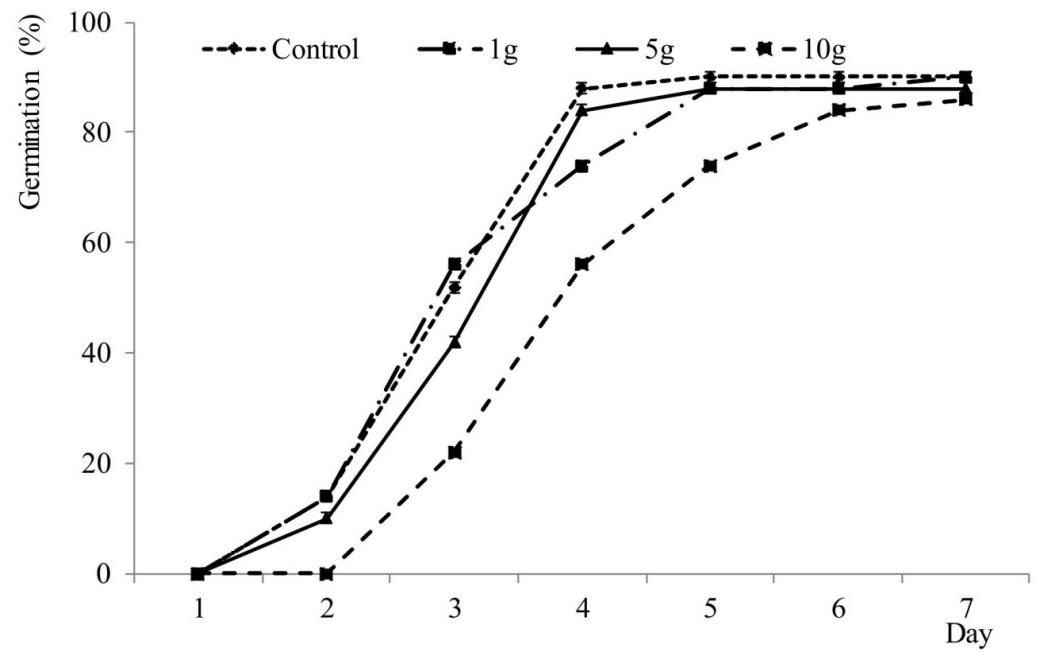

Fig. 1. Germination percentage (GP) of radish seeds Raphanus sativus L. var. radicula Pers. 'Półdługa' treated with volatile compounds released from peppermint dry leaves (Mentha xpiperita L.) at different concentrations (1, 5, $10 \mathrm{~g})$ and control conditions 
1280

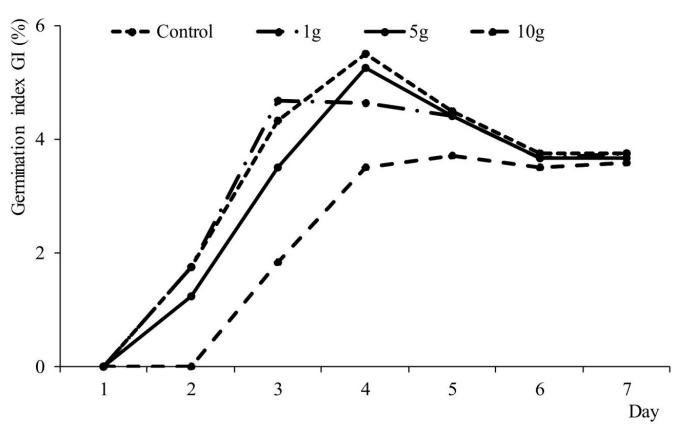

Fig. 2. Germination index (GI) of radish seeds Raphanus sativus L. var. radicula Pers. 'Półdługa' treated with volatile compounds released from peppermint dry leaves (Mentha xpiperita L.) at different concentrations $(1,5,10 \mathrm{~g})$ and control conditions

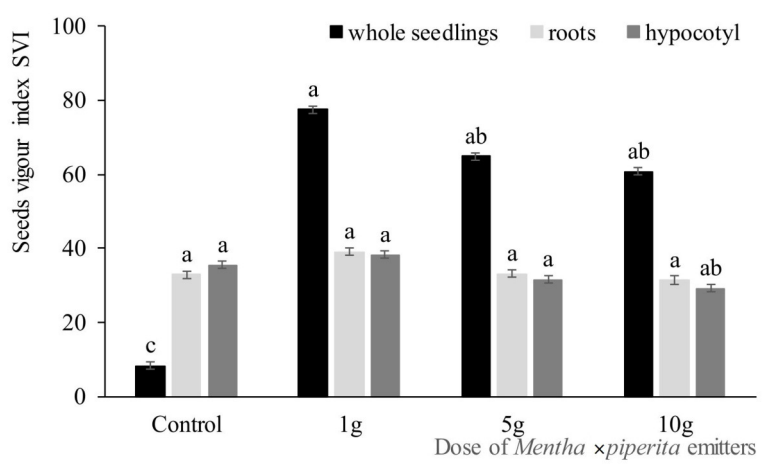

Fig. 4. Seedling vigour index (SVI) of Raphanus sativus L. var. radicula Pers. 'Półdługa' seedlings after $7^{\text {th }}$ days treated with volatile compounds released from peppermint dry leaves (Mentha xpiperita L.) at different concentrations $(1,5,10 \mathrm{~g})$ and control conditions; mean values $( \pm S D)$ marked with letters: $a, b, c$ differ significantly according to Duncan's test at $\mathrm{p}<0.05$

The time needed to germinate $50 \%$ of the total number of germinating seeds $\left(\mathrm{T}_{50}\right)$ of radish, starting from the day on which the first germinating seeds appeared, turned out to be the shortest for radish seeds treated with the highest - 10 g dose of allelopatins (Fig. 5). $\mathrm{T}_{50}$, was longer by more than half a day, for seeds germinating in conditions of $1 \mathrm{~g}$ dose of dry $M$. ×piperita leaves. Of all samples, radish seeds from the control group and those treated with a $5 \mathrm{~g}$ dose of dried material were characterised by the longest average $T_{50}$ germination time. Both tested samples needed nearly 4 days to germinate $50 \%$ of seeds.

Biometric analysis showed statistically significant inhibition of growth of radish seedlings germinating in conditions of 5 and $10 \mathrm{~g}$ dose of dry M. ×piperita leaves, compared to seedlings from the control sample (Table 2). The opposite situation occurred in the case of radish seeds germinating in the presence of $1 \mathrm{~g}$ dried mint - here the difference in the length of radish seedlings between the control and seedlings grown in the environment with $1 \mathrm{~g}$ mint emitters was as much as $10.1 \mathrm{~mm}$.

Root growth of seedlings $R$. sativus var. radicula

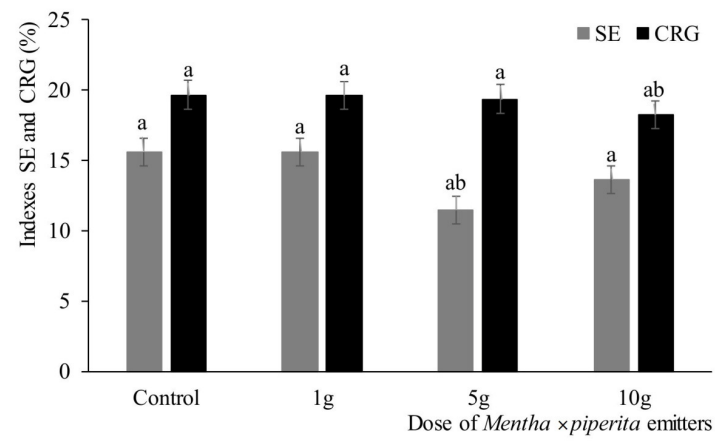

Fig. 3. Speed of emergence (SE) and coefficient of the rate of germination (CRG) of Raphanus sativus L. var. radicula Pers. 'Półdługa' seedlings after $7^{\text {th }}$ days treated with volatile compounds released from peppermint dry leaves (Mentha xpiperita L.) at different concentrations $(1,5,10 \mathrm{~g})$ and control conditions; mean values $( \pm S D)$ marked with letters: a, b, c differ significantly according to Duncan's test at $\mathrm{p}<0.05$

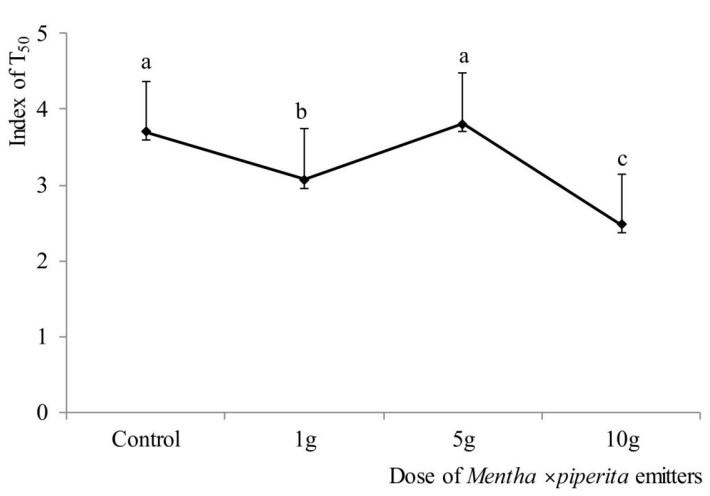

Fig. 5. Time required for $50 \%$ germination $\left(\mathrm{T}_{50}\right)$ Raphanus sativus L. var. radicula Pers. 'Półdługa' seedlings after $7^{\text {th }}$ days treated with volatile compounds released from peppermint dry leaves (Mentha xpiperita L.) at different concentrations $(1,5$, $10 \mathrm{~g})$ and control conditions; mean values $( \pm S D)$ marked with letters: a, b, c differ significantly according to Duncan's test at $\mathrm{p}<0.05$

'Półdługa' in all tested samples, except seedlings treated with $1 \mathrm{~g}$ mint emitters, was similar (Table 2). In the case of hypocotyl length, stimulation of their growth was demonstrated for seedlings grown in the presence of $1 \mathrm{~g}$ emitters from $M$. xpiperita, and inhibition of aboveground organs growth was found for seedlings treated with 10 doses of dried mint.

The stimulating effect of mint emitters at a dose of $1 \mathrm{~g}$ confirmed the growth inhibition percentage index (IP), which reached negative values here. Compared to the control, the growth of seedlings in the other two samples (5 and $10 \mathrm{~g}$ ) was inhibited, the more the dose of allelopathic compounds was higher. Considering the IP for the underground and aboveground parts of radish seedlings separately, the stimulatory effect of mint volatile compounds in all doses on the radish root was clearly observed. In the case of hypocotyls, only emitters at the lowest dose stimulated their growth (Fig. 6). 
Table 2. Length $[\mathrm{mm}]$ of radish seedlings (Raphanus sativus L. var. radicula Pers. 'Półdługa') grown in an enriched environment with volatile compounds released from peppermint dry leaves (Mentha xpiperita L.) and on control conditions (distilled water)

\begin{tabular}{ccccc}
\hline \multirow{2}{*}{ Organ } & \multicolumn{4}{c}{ Dose of Mentha $\times$ piperita emitters $[\mathrm{g}]$} \\
\cline { 2 - 4 } & Control & 1 & 5 & $37.7 \mathrm{~b} \pm 1.22$ \\
\hline Root & $36.6 \mathrm{bc} \pm 1.01$ & $43.5 \mathrm{a} \pm 1.19$ & $36.0 \mathrm{bc} \pm 0.58$ & $36.6 \mathrm{bc} \pm 1.20$ \\
Hypocotyl & $39.4 \mathrm{~b} \pm 0.53$ & $42.6 \mathrm{a} \pm 0.63$ & $73.7 \mathrm{~b} \pm 1.41$ & $70.0 \mathrm{c} \pm 0.66$ \\
Whole seedling & $76.0 \mathrm{~b} \pm 1.19$ & $86.1 \mathrm{a} \pm 1.53$ & $70.6 \mathrm{bc} \pm 1.29$ \\
\hline mean values $( \pm$ SD) marked with letters: $\mathrm{a}, \mathrm{b}, \mathrm{c}$ differ significantly (in each row) according to Duncan's test at $\mathrm{p}<0.05$
\end{tabular}

Table 3. Fresh and dry mass values and percentage water content in radish seedlings (Raphanus sativus L. var. radicula Pers. 'Póldługa') grown in an enriched environment with volatile compounds released from peppermint dry leaves (Mentha xpiperita L.) and on control conditions (distilled water)

\begin{tabular}{ccccc}
\hline \multirow{2}{*}{ Parametr } & \multicolumn{4}{c}{ Dose of Mentha $\times$ piperita emitters $[\mathrm{g}]$} \\
\cline { 2 - 4 } & Control & 1 & 5 & $0.0677 \mathrm{bc} \pm 0.02$ \\
\hline Fresh mass $[\mathrm{g}]$ & $0.0773 \mathrm{~b} \pm 0.02$ & $0.0926 \mathrm{a} \pm 0.01$ & $0.0077 \mathrm{a} \pm 0.002$ & $0.0717 \mathrm{~b} \pm 0.01$ \\
Dry mass $[\mathrm{g}]$ & $0.0060 \mathrm{a} \pm 0.002$ & $0.0069 \mathrm{a} \pm 0.002$ & $88.58 \mathrm{~b} \pm 2.74$ & $90.0067 \mathrm{a} \pm 0.003$ \\
Water content $[\%]$ & $92.25 \mathrm{a} \pm 2.22$ & $92.48 \mathrm{a} \pm 2.42$ & $90.51 \mathrm{abc} \pm 4.17$ \\
\hline mean values $( \pm$ SD) marked with letters: $\mathrm{a}, \mathrm{b}, \mathrm{c}$ differ significantly (in row) according to Duncan's test at $\mathrm{p}<0.05$
\end{tabular}

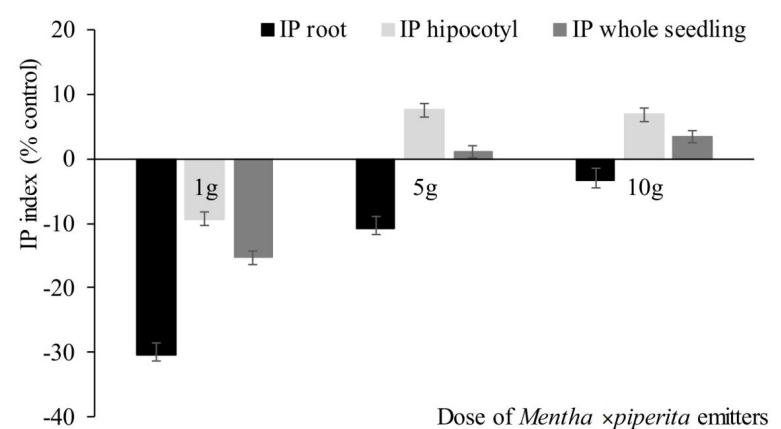

Fig. 6. Inhibition percentage (IP) of growth expressed as control percentage for root, hypocotyl and whole seedlings of Raphanus sativus L. var. radicula Pers. 'Półdługa', after $7^{\text {th }}$ days treated with volatile compounds released from peppermint dry leaves (Mentha xpiperita L.) at different concentrations (1, 5, $10 \mathrm{~g}$ ) and control conditions; a minus (-) value on the $\mathrm{Y}$ axis indicates growth, and a plus (+) value indicates growth inhibition

The fresh mass of radish seedlings grown in Petri dishes treated with allelopathic compounds at doses of 5 and $10 \mathrm{~g}$ was less than the fresh mass of seedlings from the control sample (Table 3). A clear increase in fresh mass was observed in the case of seedlings grown under the influence of mint leaf emitters at a dose of $1 \mathrm{~g}$. In the case of dry mass, an increase in its value was found for all radish seedlings, regardless of the dose of allelopathic compounds, compared to the control. These changes were not statistically significant.

Comparing the percentage of water content in radish seedlings grown in the presence of volatile compounds from dry leaves $M$. xpiperita, it was found that, in relation to control, seedlings in the $1 \mathrm{~g}$ dose of allelopatin had similar water content. The other two samples ( 5 and $10 \mathrm{~g}$ ) differed significantly, with radish seedlings treated with the $5 \mathrm{~g}$ dose definitely containing the least water, compared to seedlings from the control sample.

\section{Discussion}

Differences observed in germination process and selected phenotypic features of Raphanus sativus L. var. radicula Pers. 'Półdługa', treated with different doses of emitters from dry mint leaves $(1,5,10 \mathrm{~g})$ prove that Mentha $\times$ piperita L. has significant allelopathic properties even through its volatile compounds. The phenomenon of allelopathic interaction of different species and varieties of mint in different forms has already been observed in many experiments with crop plants (Campiglia et al., 2007; Khan et al., 2011; Bajalan et al., 2013; Islam and Kato-Noguchi, 2013a, b; Peterova et al., 2015; Skrzypek et al., 2015).

In this experiment, it was found that the germination capacity of the radish seeds of the control sample was similar to the $1 \mathrm{~g}$ dose of dried mint. In the other two biological tests, it was found that the higher the emitter dose, the lower the number of germinated seeds (Fig. 1). An analogous regularity was demonstrated by the germination index (GI), which for radish treated with the lowest $1 \mathrm{~g}$ dose of mint emitters on the third day of the experiment was even higher than GI of the radish from the control sample (Fig. 2). In the case of seed emergence of germination index (SE) similar results were also reported. In contrast, the coefficients of the rate of germination (CRG) values were similar for three samples: control, mint emitters at 1 and $5 \mathrm{~g}$ (Fig. 3). In the literature, similar values of germination indexes for the control sample and samples subjected to the lowest interaction of allelopathic compounds from aqueous solutions of peppermint leaves have already been noted. For example, Skrzypek et al. (2015) conducted studies on the allelopathic effect of $M$. xpiperita on germination and growth of common sunflower (Helianthus annuus L.). They noticed that $1 \%$ mint leaf aqueous extract resulted in the same number of germinated seeds as in the control sample, and higher concentrations $(3,5,10,15 \%)$ proved to have a clearly inhibitory effect on germination. Similarly, Mahdavikia and Saharkhiz (2015) observed that low concentrations of oil and aqueous extract from $M$. ×piperita cv. 'Mitcham' has a positive effect on germination, among others jungle rice (Echinochloa colona (L.) Link and field bindweed (Convolvulus arvensis L.). 
1282

The results obtained in this experiment are divergent with the data obtained by Peterova et al. (2015). These researchers analysed the effect of $M$. xpiperita leaf allelopathic compounds on the germination of wheat seeds (Triticum aestivum L.) and seeds associated with weed cultivation: Johnsongrass (Sorghum halepense (L.) Pers), Bermuda grass (Cynodon dactylon L.), goosefoot (Chenopodium album L.) and curly dock (Rumex crispus L.). In this case, the inhibitory effect of allelopathic substances on seed germination was noted with increasing concentrations of mint extracts. Additionally, the $5 \%$ aqueous extract turned out to be lethal for all acceptor plants. Campiglia et al. (2007) reported a similar, inhibitory effect of allelo-chemical compounds with $M$. ×piperita at various concentrations in tests with red-root amaranth (Amarantus retroflexus L.), wild mustard (Sinapis arvensis L.) and ryegrass (Lolium spp.). Bajalam et al. (2013) also observed similar results in experiments on the impact of aqueous horse mint extract (Mentha longifolia (L.) L., syn. M. sylvestris L.) on the germination of two cultivars of wheat (T. aestivum L. 'Azar' and 'Alvand') and red-root amaranth. These researchers observed decreasing values of seed germination indexes of the above-mentioned taxa along with the increase in the concentration of allelopathic substances with $M$. longifolia.

Examples of inhibitory and / or stimulating effect of allelopathic compounds from mint (various species) on the growth of seedlings of various plant species have been noted, among others by Khan et al. (2011), Islam and KatoNoguchi (2013a, b). For example, in an experiment carried out by Khan et al. (2011), the M. longifolia extract caused a significant inhibition of growth of both shoots and roots of wheat, together with an increase in the concentration of allelopathic compounds. These results do divergent with the present experiment, because here the growth inhibition percentage index (IP) showed that the $M$. xpiperita emitters at a dose of $1 \mathrm{~g}$ were clearly stimulating for radish seedlings, both on the root and hypocotyl (Fig. 6). Similar results in terms of mint allelopathic-stimulators for aboveground parts of plants have been observed, e.g. by Islam and KatoNoguchi (2013b). These authors noticed the effect of the aqueous extract from $M$. longifolia in various concentrations on cress (Lepidum sativum L.), lettuce (Lactuca sativa L.), lucerne (Medicago sativa L.), oilseed rape (Brassica napus L.), timothy grass (Phleum pratense L.), hairy crabgrass (Digitaria sanguinalis (L.) Scop.), cockspur (Echinochloa crus-galli (L.) P. Beauv.) and Italian ryegrass (Lolium multiflorum Lam.). For these plants, except to cress, low concentrations of allelopathic compounds from $M$. longifolia stimulated the growth of aboveground parts, and high clearly inhibited them.

In another experiment of the same authors (Islam and Kato-Noguchi, 2013a), the positive effect of allelopathic substances from $M$. longifolia was also observed in lower concentrations on the growth of cockspur coleoptiles. In the case of root length growth, the results of the radish experiment (Table 2) are divergent with the results obtained by the above-mentioned authors. Of the 8 species studied by Islam and Kato-Noguchi (2013b), only for three (oilseed rape, timothy grass and hairy crabgrass) were found to have a stimulating effect of mint allelochemical compounds on root growth. In case of E. crus-galli, each of the allelopathic concentrations used had a root growth inhibitory effect (Islam and Kato-Noguchi, 2013a). Similarly as in the experiment with radish, the relationship of the beneficial effect of allelopathic solutions with $M$. xpiperita at a low concentration on root growth was demonstrated by Mahdavikia and Saharkhiz (2015), in tests concerning the previously mentioned field bindweed and purslane (Portulaca oleracea L.).

The research shows that the treatment of radish seeds with volatile compounds from $M$. ×piperita causes not only changes in germination indexes (Figs. 4 and 5), but also differences in the growth of seedlings, which also has a consequent effect on increase of fresh and dry mass of these seedlings (Table 3 ). The fresh mass of radish seedlings growing in the environment with a $1 \mathrm{~g}$ dose of mint allelopathic compounds reached significantly higher values. The other two samples $(5,10 \mathrm{~g})$ showed a lower fresh mass compared to the control. Similar results were noticed for the dry mass of radish seedlings. In the literature, only different results of similar experiments can be found in which, with the increase of the concentration of allelopathic compounds, the mass of seedlings decreases, compared to control samples (Khan et al., 2011; Bajalan et al., 2013). Both Khan et al. (2011), as well as Mahdavikia and Saharkhiz (2015) reported a lower value of fresh mass in each of the mint allelopathic concentrations used.

Peppermint is one of many popular aromatic plants rich in numerous chemical compounds that have an intense effect on plants growing nearby (Peterova et al., 2015; Skrzypek et al., 2015; Możdżeń et al., 2016). This thesis is also confirmed by this experiment using different doses of volatile substances released from its leaves. There are still few researches in the literature studying the effects of plants based on volatile substances secreted by them (Najda, 2015), which further affects the relevance of choosing this topic. However, it is also necessary to conduct research on this allelopathic-active species, which will allow the isolation of its natural substances that could be used in the currently fashionable organic farming (Duke et al., 2000). It is natural allelopathic compounds, such as those contained in mint, that play an important role in the natural environment, and the interactions learned between selected species enable their use in agricultural practice (Stokłosa, 2006).

\section{Conclusions}

The germination indexes for Raphanus sativus L. var. radicula Pers. 'Półdługa' showed the stimulating effect of emitters released from the dry leaves of Mentha xpiperita L. at the lowest $1 \mathrm{~g}$ dose; at a low dose of allelopathic compounds, the seeds germinated similarly to the control, and even more often, when the mint doses increased, germination was slightly inhibited. The increase in the length of coleoptiles and whole seedlings of the analysed radish cultivar decreased with the increase in allelopathic substances dose; compared to the control, only for root growth stimulation was noted, irrespective of the dose of mint leaf emitters. Values of fresh and dry mass and water content were highest in radish seedlings grown in the 
environment with the lowest $1 \mathrm{~g}$ emitter dose; as the dose of mint increased, a slight decrease was observed in these parameters compared to the control.

\section{Acknowledgements}

The research was supported by the grant of BS $663 / \mathrm{G} / 2019$

\section{Conflict of Interest}

The authors declare that there are no conflicts of interest related to this article.

\section{References}

Association of Official Seed Analysis (AOSA) (1983). Seed vigour testing Handbook. Handbook on Seed Testing, Contribution no. 32.

Bajalan I, Zand M, Rezaee S (2013). The study on allelopathic effects of Mentha longifolia on seed germination of velvet flower and two cultivars of wheat. International Research Journal of Applied and Basic Sciences 4(9):2539-2543.

Beevi SS, Mangamoori LN, Gowda BB (2012). Polyphenolics profile and antioxidant properties of Raphanus sativus (L). Natural Product Research 26(6):557-563.

BeeviSS, Mangamoori LN, Subathra M, EdulaJR(2010). Hexane extract of Raphamus sativus L.rootsinhibits cell proliferation and induces apoptosis in human cancer cells by modulating genes related to apoptotic pathway. Plant Foods for Human Nutrition 65(3):200-209.

Bewley JD, Black M (1985). Seeds: physiology of development and germination. Plenum Press. USA, New York.

Campigitia E, Mancinelli R, Cavalieri A, Caporal (2007). Use of essential oils of cinnamon, lavender and peppermint for weed control. Italian Journal of Agronomy 58(2):171-175.

Chiapusio G, Sanchez AM, Reigosa MJ, Gonzalez L, Pellissier F (1997). Do germination indices adequately reflect allelochemical effects on the germination process?Journal of Chemical Ecology 23(11):2445-2453.

Coolbear P, Francis A, Grierson D (1984). The effect of low temperature pre-sowing treatment on the germination performance and membrane integrity of artificially aged tomato seeds. Journal of Experimental Botany 35(11):1609-1617.

Derwich E, Benziane Z, Taouil R, Senhaji O, Touzani M (2010). Aromatic plants in Morocco: GC/MS analysis of essential oils of leaves of Mentha piperita. Advances in Environmental Biology 4:80-85.

DukeSO, Dayan FE, RomagniJG, Rimando AM (2000).Natural products as sources of herbicides: current status and future trends. Weed Research 40(1):99-111.

Eteghad SS, Mirzaei M, Pour SF, Kahnamui S (2009). Inhibitory effects of endemic Thymus vulgaris and Mentha piperita essential oils on Escherichia coli O157:H7. Research Journal of Biological Sciences 4(3):340:344.

Farooq M, Basra SMA, Afzal I, Khaliq A (2006). Optimization of hydropriming techniques for rice seed invigoration. Seed Science and Technology34(2):507-512.
Finch S, Billiald H, Collier RH (2003). Companion planting - do aromatic plants distupt host-plant finding by the cabbage root fly and the onion fly more effectively than non-aromatic plants. Entomologia Experimentaliset Applicata 109(3):183-195.

Inderjit, Duke SO (2003). Ecophysiological aspects of allelopathy. Planta 217(4):529-539.

Islam AKMA, Anuar N, Yaakob Z (2009). Effect of genotypes and presowing treatments on seed germination behavior of Jatropha. Asian Journal of PlantSciences 8(6):433-439.

Islam AKMM, Kato-Noguchi H (2012). Allelopathic potentiality of medicinal plant Lencas aspera. International Journal of Agricultural Sustainability 4(1):1-7.

Islam AKMM, Kato-Noguchi H (2013a). Allelopathic potential of five Labiatae plant species on barnyard grass (Echinochloa crus-galli). Australian Journal of Crop Science 7(9):1369-1374.

Islam AKMM, Kato-Noguchi H (2013b). Mentha sylvestris: a potential allelopathic medicinal plant. International Journal of Agriculture and Biology 15(6):1313-1318.

Khan RA, Khan F, Ahmed M, Shah AS, Khan NA, Khan MR, Shah MS (2011). Phytotoxic and antibacterial extract of Mentha longifolia (Linn.). African Journal of Pharmacy and Pharmacology 5(12):1530:1533.

Kizil S, Hasimi N, Tolan V, Kilinc E (2010) Mineral content, essential oil components and biological activity of two mentha species (M. piperita L,M.spicata L). Turkish Journal of Field Crops 15(2):148-153.

Kohlmünzer S (2005). Pharmacognosy. Wydawnictwo Lekarskie PZWL, Warszawa, Poland.

Krawiec M, Dziwulska-Hunek A, Kornarzyński K, Palonka S (2012). Wplyw wybranych czynników fizycznych na kietkowanie nasion rzodkiewki (Raphamus satious $\mathrm{L}$ ) [The effect of selected physical factors on the germination of radish (Raphanus sativus L.) seeds]. Acta Agrophysica 4(19):737-748.

Macias FA, Marin D, Oliveros-Bastidas A, Varela RM, Simonet AM, Carrera C, Molinillo JM (2003). Allelopathy as a new strategy for sustainable ecosystems development. Biological Science in Space 17(1):18-23.

Mahdavikia F, Saharkhiz MJ (2015). Phytotoxic activity of essential oil and water extract of peppermint Menthapiperita L. cv. 'Mitcham'.Journal of Applied Research on Medicinal and Aromatic Plants2(4):146-153.

Molisch H (1937). Der Einfluss einer Pflanze auf die andere. Allelopathie [The influence of one plant on the other. Allelopathy].Jena, Germany Verlangvon Gustav Tischer.

Najda A (2015). Roślinne substancje lotne - oljki eteryczne [Plant volatile substances-essential oils]. Episteme 27(2):65-77.

Najda A (2017).Skład chemicznyi działanie przeciwutleniajace ekstraktów z Mentha $x$ piperita L. [Chemical composition and antioxidant activity of extractsfrom Mentha × piperita L.].Postępy Fizjoterapii 4:251-258.

Petrova ST, Valcheva EG, Valchewa IG (2015). A case study of allelopathic effect of weeds in wheat. Ecologia Balkanica 7(1):121-129.

RiceEL (1984).Allelopathy.Academic Press,New York, USA pp 8-22.

Singh R, Muftah AM, Belkheir A (2015). Antibacterial and antioxidant activities of Mentha piperita (L). Arabian Journal of Chemistry 89(3):322-328. 
1284

Skrzypek E, Repka P, Stachurska-Swakoń A, Barabasz-Krasny B, Możdżeń K (2015). Allelopathic effect of aqueous extracts from the leaves of peppermint (Mentha $\times$ piperita $\mathrm{L}$.) on selected physiological processes of common sunflower (Helianthus annuus L.). Notulae Botanicae Horti Agrobotanici Cluj-Napoca 43(2):335-342.

Skrzypek E, Repka P, Stachurska-Swakoń A, Barabasz-Krasny B, Możdżeń $K$ (2016). Seedlings growth of common sunflower under influence of peppermint extract. Modern Phytomorphology 9:69-73.

Stokłosa A (2006). Bioherbicydy i alleloherbicydy w walce z chwastami [Bioherbicides and alleloherbicides in the fight against weeds]. Postępy Nauk Rolniczych 6:41-50.
Willis RJ (2007). The history ofallelopathy.Springer, Berlin, Germany.

Zeng R (2008). Allelopathy in Chinese ancient and modern agriculture. In: Zeng R, Mallik A, Luo S (Eds). Allelopathy in sustainable agriculture and forestry. Springer Press, New York, USA pp 39-59.

Zeng RS (2014). Allelopathy-the solution is indirect. Journal of Chemical Ecology 40(6):515-516. 